\title{
MOBILE LEARNING BERBASIS ANDROID SEBAGAI MEDIA PEMBELAJARAN PENDIDIKAN AGAMA ISLAM
}

\author{
Sofia Zaini Kulbi \\ Pascasarjana Universitas Islam Negeri Sunan Ampel Surabaya, Indonesia \\ 99sofiaputri@gmail.com
}

Received: 15-06-2019

Revised: 10-10-2019

Accepted: 05-11-2019

\begin{abstract}
Advances in communication technology affect all aspects including aspects of education. An educator is required to create active, effective and fun teaching and learning activities. Related to this, the learning of Islamic Religious Education (PAI) is generally still monotonous in using learning media so that students feel bored in learning PAI. PAI's teacher at SMK Wabana Karya tries to make an innovation in Islamic Education learning, namely by using Android-based mobile learning. This is based on the background of students who on average already use Android in everyday life. So, this study describes android-based mobile learning as a learning medium for Islamic religious education at SMK Wahana Karya. This research uses qualitative methods, where the researcher makes direct observations and interviews. Sources of data used are from school archives, school websites, interviews with principals, Islamic education teachers and students of SMK Wahana Karya. The results of this study are, although there are still some obstacles, namely in terms of signal and classroom atmosphere conditioning. However, apart from that the use of mobile learning is considered effective, and attracts students in learning Islamic Education.
\end{abstract}

Keyword: Mobile Learning, Android and Islamic Religious Education

\section{Abstrak}

Kemajuan teknologi komunikasi mempengaruhi segala aspek termasuk aspek pendidikan. Seorang pendidik dituntut untuk menciptakan kegiatan belajar mengajar yang aktif, efektif dan menyenangkan. Terkait dengan hal tersebut pada pembelajaran Pendidikan Agama Islam (PAI) umumnya masih monoton dalam menggunakan media pembelajaran sehingga peserta didik merasa jenuh dalam pembelajaran PAI. Guru PAI di SMK Wahana Karya mencoba membuat suatu inovasi pada pembelajaran PAI yaitu dengan menggunakan mobile learning berbasis android. Hal ini dilatar belakangi oleh peserta didik yang rata-rata sudah menggunakan android dalam kehidupan sehari-hari. Maka, penelitian ini memaparkan tentang mobile learning berbasis android sebagai media pembelajaran pendidikan agama Islam di SMK Wahana Karya. Penelitian ini menggunakan metode kualitatif, dimana peneliti melakukan observasi dan wawancara secara langsung. Sumber data yang digunakan adalah dari arsip sekolah, website sekolah, wawancara kepala sekolah, guru PAI dan siswa siswi SMK Wahana Karya. Hasil dari penelitian ini adalah, meski masih ada beberapa kendala yaitu dari segi sinyal dan pengkondisian suasana kelas. Namun, terlepas dari hal itu penggunaan mobile learning dirasa efektif, dan menarik peserta didik dalam pembelajaran PAI.

Kata Kunci: Mobile learning, Android, Pendidikan Agama Islam 


\section{PENDAHULUAN}

Teknologi dan komunikasi mempunyai andil yang begitu penting dalam kehidupan pada era digital ini. Dalam ranah pendidikan, teknologi komunikasi menawarkan kemudahan dalam proses kagiatan pembelajaran salah satunya pembelajaran dengan menggunakan konsep (M-learning) Mobile Learning. Konsep pembelajaran mobile learning ini adalah suatu konsep lanjutan dari e-learning. Jika pembelajaran e-learning mencakup computer based learning, web based learning, virtual classroom. E-learning pun memiliki konsep pembelajaran melalui semua perangkat media teknologi termasuk internet, intranet, satelit broadcast, TV, audio, radio dan sebagainya. ${ }^{1}$

Beda halnya dengan mobile learning, mobile learning mempunyai konsep pembelajaran dengan menggunakan perangkat mobile seperti android, smartphone, tablet yang memiliki penyimpanan lebih terbatas. Konten yang disajikan oleh mobile learning umumnya berupa text dan gambar tetapi dengan seiring kemajuan teknologi saat ini konten berupa video, animasi dan audio pun sudah bisa digunakan dalam pembelajaran mobile learning. ${ }^{2}$

Menggunakan mobile learning dapat membantu meningkatkan efisiensi dan efektivitas dalam pembelajaran khususnya dalam pembelajaran pendidikan agama Islam. Karena pembelajaran pendidikan agama Islam (PAI) kerapkali mengalami hambatan dalam memberikan inovasi dibanding dengan pembelajaran lain, tidak terkecuali SMK Wahana Karya Surabaya. Peserta didik dapat belajar dirumah dengan menggunakan smartphone yang dimiliki. SMK Wahana Karya adalah salah satu SMK swasta formal yang menerapkan sistem pembelajaran daring di kala pembelajaran jarak jauh. Dalam hal ini, para guru PAI di SMK Wahana Karya memiliki berbagai inovasi dalam pembelajran baik jarak jauh ataupun pembelajaran di sekolah. Beragam inovasi yang digunakan pembelajaran PAI menggunakan platform mobile learning yang berbasis android.

Mobile learning berbasis android dapat menjadi sebuah solusi dan inovasi dalam pembelajaran PAI. Terlebih, pembelajaran PAI yang berbasis android juga merupakan wujud dari perkembangan informasi dan komunikasi yang memanfaatkam kecanggihan smartphone mobile. Android menyediakan berbagai platform terbuka sebagai media pembelajaran, selain itu seseorang juga dapat menciptakan platform pembelajaran berupa

1 Ziaurrahman, Herman Dwi Surjono, "Pengembangan E-Learning Adaptif Pada Mata Pelajaran Pendidikan Agama Islam Untuk Kelas X SMA”, Jurnal Inovasi Teknologi Pendidikan, Vol. 4, No. 2 (Oktober 2017), 116-120.

2 Musahrain, Nunuk Suryani dan Suharno, "Pengaplikasian Mobile LearningSebagai Media dalam Pembelajaran", Prosiding Seminar Pendidikan Nasional Pemanfaatan Smartphone untuk Literasi Produktif Menjadi Guru Hebat dengan Smartphone, Pascasarjana Teknologi Pendidikan FKIP Universitas Sebelas Maret (2017), 127-130. 
aplikasi di android. Pembelajaran mobile learning dijalankan di SMK Wahana Karya dilatar belakangi oleh peserta didik yang hampir seluruhnya adalah pengguna gadget android. ${ }^{3}$

Pendidik berharap mobile learning memberikan dampak yang positif, seperti pemanfaatan smartphone yang dimiliki peserta didik agar tidak digunakan untuk hal-hal yang negative melainkan berguna untuk pembelajaran dan mencari sumber referensi untuk materi. Detail pembelajaran PAI di SMK Wahana Karya Surabaya melalui mobile learning akan dipaparkan secara detail dalam tulisan ini. Dengan demikian, secara teoretis hasil penelitian ini diharapkan mampu meningkatkan kualitas pembelajaran PAI dengan menggunakan teknologi informasi di zaman sekarang khususnya dengan menggunakan android dan platform-platform pembelajaran yang tersedia.

\section{KAJIAN TEORETIS}

\section{Mobile Learning Berbasis Android}

Istilah mobile learning terdiri dari kata mobile dan learning. Kata mobile artinya ponsel atau handphone, learning memiliki arti pembelajaran. maka mobile learning adalah pembelajaran dengan memanfaatkan handphone cerdas sebagai bagian dari proses pembelajaran. ${ }^{4}$ Beragam inovasi dan fitur yang disediakan teknologi smartphone saat ini dapat menunjang keberhasilan pembelajaran menggunakan konsep mobile learning. Perangkat mobile bersifat handy, portable dan dapat selalu aktif, hal ini akan bermanfaat dalam mangakses konten pembelajaran secara tepat dan cepat. Karena dapat diakses dimanapun dan kapanpun tanpa perlu menghidupkan perangkat computer.

Mobile learning juga dapat diartikan sebagai suatu kegiatan pembelajaran yang mana seorang pembelajaran dan pengajar tidak diharuskan berada diam di dalam suatu tempat untuk menghadiri kelas tertentu. Tetapi peserta didik dan pendidik hanya perlu untuk menggunakan smartphone dalam mengakses pembelajaran, hal ini dapat dilakukan baik dalam ruangan ataupun dalam ruang publik tanpa dibatasi oleh ruang dan waktu tertentu. $^{5}$

Sedangkan android merupakan sistem operasi yang berbasis linux, dirancang untuk perangkat bergerak dengan sistem touchscreen layar sentuh seperti smartphone dan

\footnotetext{
${ }^{3}$ Nurdyansyah dan Fahyuni E.F, Inovasi Model Pembelajaran: Sesuai Kurikulum 2013 (Sidoarjo: Nizamial Learning Centre, 2016), 1-2.

${ }^{4}$ Nahdliyyatul 'Azimah, Rahman Hakim, "Eksplorasi Pembelajaran M-learning Fiqh pada Masa Pandemi di UIN Sunan Ampel Surabaya, Jurnal Atthulab: Islamic Religion Teacbing \& Learning Journal, Vol. 5 No. 2 (2020), 258-260.

5 Siti Muyaroah dan Mega Fajartia, Pengembangan Media Pembelajaran Berbasis Android dengan menggunakan Aplikasi Adobe Flash CS 6 pada Mata Pelajaran Biologi, IJCET Vol 6 No 2 tahun 2017), 79-83
} 
tablet. Pada awalnya android dikembangkan oleh Andorid, Inc yang diberi investasi oleh Google. Namun pada tahun 2005 sistem android dibeli oleh google, saat bersamaan dengan dimulainya open handset alliance, konorsium yaitu perusahaan-perusahaan perangkat keras, perangkat lunak dan telekomunikasi yang ditujukan untuk membuat pembaharuan tentang standart terbuka perangkat seluler. Ponsel android mulai diedarkan pada bulan Oktober 2008. Sistem operasi android memiliki berbagai macam versi. Setiap versi mempunyai kelebihan tersendiri, mulai dari tampilan, sistem keamanan dan sebagainya. $^{6}$

Terdapat beragam jenis konten pembelajaran yang disuguhkan oleh mobile learning. Berbagai macam konten ini dapat dikembangkan sesuai dengan karakteristik perangkat atau devise dan penggunanya. Konten-konten tersebut diantaranya:

Teks: Semua handphone dan smartphone yang digunakan saat ini mendukung penggunaan teks. Hal ini dikarenakan memori yang disediakan dalam smartphone memiliki kapasitas yang kecil, maka konten pembelajaran melalui teks mudah diterapkan dalam pembelajaran. pembelajaran melalui text juga lebih flexible dapat digunakan dimana saja. Tetapi keterbatasannya adalah tidak ada interaksi secara langsung karena hanya sebatas membaca teks.

Gambar: Smartphone juga menyediakan akses pemakaian gambar. Kualitas ambar yang diberikan ada beberapa tipe, mulai tipe gambar berwarna yang memiliki kualitas tinggi hingga yang rendah, bergantung dengan kemampuan perangkatnya. Jenis file yang didukung oleh device adalah seperti PNG, GIF, JPG.

Audio: Perangkat mobile juga mendukung adanya penggunaan audio. Beragam jenis tipe yang dapat digunakan dalam perangkat seperti tipe $\mathrm{Rm}, \mathrm{Mp} 3$, amr, dan lain-lain. File audio umumnya mempunya kapasitas yang cukup besar, sehingga terkadang file audio tidak mencukupi untuk diakses di perangkat mobile tertentu. Namun terdapat alternatif agar file audio bisa dapat diakses pada perangkat yang ukuran memorinya kecil. File audio harus diolah terlebih dahulu dengan cara mengkompres file, agar ukuran kapasitas file menajdi lebih kecil.

Video: Beberapa perangkat mobile zaman sekrang sudah mampu meakses file video. Tipe file yang didukun goleh perangkat seperti 3gp, MPEG, MP4 dan sebagainya. Sama halnya seperti file audio, umumnya file video mempunyai ukuran yang besar sehingga harus dikompres agar sesuai dengan ukuran perangkat yang dimiliki.

\section{${ }^{6}$ Ibid.,}


Aplikasi Perangkat Lunak (Software): Dalam mobile learning berbasis android juga terdapat aplikasi perangkat lunak. Aplikasi perangkat lunak dapat digunakan sesuai dengan kebutuhan pengguna. Beragam aplikasi yang inovatif ditawarkan dalam mobile learning, mulai dari aplikasi untuk pendidikan, bisnis, ilmuilmu keislaman dan sebagainya. Aplikasi perangkat lunak (software) dapat menggabungkan beberapa konten lain seperti teks, audio dan video sehingga aplikasi dapat berjalan secara interaktif.

Mobile learning memiliki tiga fungsi dan manfaat dalam kegiatan pembelajaran di dalam kelas. Pertama, sebagai suplement (tambahan) yang bersifat opsional. Dalam hal ini peserta didik memiliki hak bebas memiliki dalam memanfaatkan materi mobile learning atau tidak. Namun meski bersifat opsional, peserta didik dianjurkan untuk memanfaatkan mobile learning agar memiliki wawasan dan pengetahuan yang luas, serta dipermudah dalam kegiatan pembelajaran. ${ }^{7}$

Kedua, fungsi mobile learning sebagai Komplemen atau pelengkap, artinya adalah mobile learning digunakan untuk melengkapi materi pembelajaran di dalam kelas. Materi dalam mobile learning menjadi penguatan atau reinforcement untuk peserta didik dalam proses kegiatan pembelajaran. Ketiga, mobile learning sebagai pengganti atau substitusi. Beberapa lembaga pendidikan di negara maju baik itu universitas dan sekolah-sekolah mempunyai alternative dalam pembelajaran yang dapat digunakan. ${ }^{8}$

Terdapat tiga alternative, yaitu sepenuhnya tatap muka, sebagian tatap muka dan sebagian pertemuan melalui jejaring internet dan sepenuhnya pertemuan melalui internet. Mobile Learning berbasis android juga dapat memudahkan komunikasi antara peserta didik dan materi pembelajaran. Peserta didik antar satu dengan yang lainnya juga dapat sharing informasi tentang materi pembelajaran atau berbagai hal yang dapat membuat peserta didik berkembang penetahuannya. Seorang pendidik dapat memberikan bahan ajar dan tugas untuk peserta didik melalui mobile learning yang berbasis android, yang dapat diakses dengan mudah oleh peserta didik. ${ }^{9}$

7 Musahrain, Nunuk Suryani dan Suharno, "Pengaplikasian Mobile LearningSebagai Media dalam Pembelajaran".

${ }^{8}$ Bahar Nur Batubara, "Pengembangan Media Pembelajaran Pendidikan Agama Islam berbasis Android di SMA UII Yogyakarta" (Tesis diterbitkan di Pascasarjana Fakultas Tarbiyah dan keguruan Universitas Islam Negeri Sunan Kalijaga, 2017), 24-26.

9 Rahmat Hidayat Hanafi, "Desain Media Pembelajaran Pendidikan Agama Islam Berbasis Aplikasi Android Materi Pengurusan Jenazah Untuk Siswa Kelas XI Sekolah Menengah Kejuruan”, Jurnal Atthulab, Vol. IV, No 1 (2019), 90-91. 


\section{Definisi dan Tujuan Pendidikan Agama Islam}

Kata pendidikan berasal dari bahasa Arab yaitu "Tarbiyyab" yang bermula dari kata "Rabbi” yang memiliki arti memberi pendidikan moral dan akhlak. Dalam pendidikan agama Islam memiliki beberapa ciri khas. ${ }^{10}$ Kalimat pendidikan agama Islam, mengandang makna dan memiliki lingkup yang luas. Karena dalam konsep tarbiyah dalam islam mengandung makna yang dalam antara Habluminallah dan Habluminannas, selainn konsep tersebut pendidikan dalam islam juga mencakup pendidikan formal dan pendidikan non formal. ${ }^{11}$

Secara universal tujuan dari pendidikan agama Islam adalah untuk dapat membentuk peserta didik menjadi manusia yang menaati ajaran agama Islam. Sehingga dapat menjadi seorang muslim dan muslimah yang sesuai dengan syariat Islam. Dalam pembelajaran pendidikan agama Islam terdapat beragam materi yang dapat menuntun peserta didik untuk menjadi muslim dan muslimah yang sesuai syariat. ${ }^{12}$ Menurut Athiyah al-Abrasyi, aspek moral adalah aspek yang utama. Dengan peserta didik mempelajari pendidikan agama Islam, peserta didik diharapkan dalam setiap gerak dan langkahnya menerapkan moral, dan budi pekerti yang baik. ${ }^{13}$

\section{Inovasi Pembelajaran}

Inovasi dalam pembelajaran terkait dengan pembaharuan dari sesuatu hal yang sudah ada. Selain itu inovasi adalah praktik dari penerapan akan sesuatu hal. Suatu inovasi pasti memiliki hal yang baru, jika dalam inovasi tidak ada hal baru, maka bukan disebut sebagai inovasi. Dalam kegiatan pembelajaran inovasi harus dilakukan oleh tenaga pendidik baik itu kepala sekolah atau guru kelas. Guru menciptakan inovasi guna memperbaruhi konsep pembelajaran agar tidak monoton dan sesuai dengan perkembangan zaman, namun harus sesuai dengan tujuan pembelajaran. ${ }^{14}$

Terlebih saat ini mewabah virus covid 19, kegiatan pembelajaran di haruskan dilakukan di rumah. Dalam situasi seperti ini pendidik tentu membutuhkan suatu inovasi dalam kegiatan pembelajaran. Serta pendidik juga harus menemukan cara agar kegiatan pembelajaran tetap berjalan meski sedang ada pandemi covid 19. Adanya pandemi covid

\footnotetext{
10 Zakiyah Drajat, Ilmu Pendidikan Islam (Jakarta: Bumi Aksara, 2012), 25.

11 Azyumardi Azra, Pendidikan Islam Tradisi dan Modernisasi Menuju Millennium Baru (Jakarta: Logos Wacana Ilmu, 1999), 5.

12 Anwar Sutoyo, Manusia dalam Perspektif al-Qur'an (Yogyakarta: Pustaka Pelajar, 2015), 3. 1970), 90.

13 Muhammad Athiyah al-Abrasyi, Dasar-Dasar Pokok Pendidikan Agama Islam (Jakarta: Bulan Bintang,

14 Syafaruddin, Inovasi Pendidikan: Suatu Analisis Terbadap Kebijakan Baru Pendidikan, (Perdana Publishing: 2018), 78.
} 
19 ini menuntut pendidik untuk inovatif, terampil dan kreatif. Maka dalam hal ini, pendidik menggunakan pembelajaran melalui sistem daring (dalam jaringan) atau pembelajaran jarak jauh selama pandemi covid 19, terlebih zaman sekarang pembelajaran daring didukung oleh kecanggilan teknologi dan informasi salah satunya mobile learning. ${ }^{15}$

Inovasi pembelajaran ditunjukkan dengan adanya pembelajaran daring, karena pembelajaran daring menggunakan konsep utama yaitu teknologi di era digital sekarang. ${ }^{16}$ Inovasi Media pembelajaran dengan mobile learning tentu tidak mudah dikuasai. Perlu ada bimbingan dari yang ahli agar peserta didik dan pendidik terbiasa untuk menggunakan mobile learning sebagai media pembelajaran.Perlu diketahui bahwa inovasi harus tetap ada dan terus dilakukan dalam pembelajaran, jadi inovasi dalam pembelajaran bersifat dinamis. ${ }^{17}($

Inovasi dalam pembelajaran dapat dikatakan berhasil jika mempunyai empat karakter, pertama adanya manfaat yang baik bagi pembuat inovasi dan pengguna. Kedua, adanya sifat yang kompatibel, keserasian antara nilai dan kebutuhan sasaran. Ketiga, bersifat kompleksitas artinya dapat mencakup keseluruhan. Keempat, mempunyai sifat triabilitas yaitu inovasi yang dapat dicoba dalam kehidupan pengguna inovasi. Kelima, bersifat observabilitas suatu inovasi yang dapat diketahui dengan benar hasil dan manfaatnya. ${ }^{18}$

\section{METODOLOGI PENELITIAN}

Pendekatan yang digunakan dalam penelitian ini adalah pendekatan kualitatif. Dimana penelitian kualitatif adalah penelitian naturalistik karena penelitiannya dilakukan pada kondisi yang alamiah mengasumsikan bahwa kenyataan-kenyataan empiris terjadi dalam suatu konteks sosio kultural yang saling terkait satu sama lain. ${ }^{19}$ Oleh karena itu penelitian secara alamiah ini akan digunakan untuk mengambil data di lapangan tentang Mobile Learning Berbasis Android (Smarthphone) Sebagai Media Pembelajaran Pendidikan Agama Islam Di SMK Wahana Karya Surabaya.

Berdasarkan objeknya, jenis penelitian ini adalah penelitian lapangan field research yang dilakukan secara langsung untuk memaparkan kondisi yang ada. Namun disamping menggunakan field research, penelitian ini juga menggunakan library riset untuk bahan

15 A. Arsyad, Media Pembelajaran (Jakarta: Rajagrafindo Persada, 2014), 53.

16 Rusadi, B. E., Widiyanto, R., dan Lubis, R. R, Analisis Learning And Inovation Skills Mahasiswa PAI Melalui Pendekatan Saintifik Dalam Implementasi Keterampilan Abad 21, Conciencia, Vol. XIX, No. 2 (2019), 112-131.

${ }_{17}$ Syaafaruddin dan Anzizhan, Psikologi Organisasi dan Manajemen (Prenada Media Group, 2018),

18 Syafaruddin, Inovasi Pendidikan; Suatu Analisis Terbadap Kebijakan Baru Pendidikan.

${ }^{19}$ Lexy J. Moleong, Penelitian Kualitatif (Bandung: Remaja Rosda Karya, 2001), 4. 
penunjang yaitu dengan studi pustaka yang menggunakan bahan literature terkait yang memeiliki informasi dan relevansi dengan topik penelitian. Jenis pokok pembahasan penelitian ini adalah terkait Mobile learning berbasis android sebagai media pembelajaran PAI $^{20}$ Teknik Pengumpulan Data dalam penelitian kualitatif dan literasi ialah wawancara mendalam (tidak terstuktur), observasi pada Kegiatan Belajar Mengajar (KBM), dokumentasi riset participant, pengamatan dan studi pustaka, menelaah berbagai buku terkait judul yang diangkat.

Sumber data yang diperlukan dalam penelitian ini terdapat tiga sumber yaitu Kepala Sekolah SMK Wahana Karya Surabaya, Guru PAI kelas X, XI, dan XII serta beberapa siswa dan siswi SMK Wahana Karya Surabaya. Dalam pencarian sumber data, peneliti memerlukan observasi selama dua hari. Pengumpulan data dilakukan dengan triangulasi data yaitu menghubungakn pendapat dari ketiga jenis informan dan serta peneliti harus mensinkronkan pendapat dengan realita yang ada. Metode analisa yang digunakan adalah deskriptif kualitatif.

\section{TEORI}

Dalam hal ini penulis memberikan beberapa penelitian terdahulu yang subyek atau objeknya terkait dengan Open Educational Resources pada Pembelajaran Pendidikan Agama Islam. Terdapat berbagai referensi yang dapat menjadi rujukan sebagai penunjang dalam artikel ini. Referensi tersebut ada dari berbagai macam karya ilmiah, yaitu dari jurnal, artikel dan tesis.

Pertama adalah tulisan Rahmat Hidayat Hanafi dari Pascasarjana Program Pendidikan Agama Islam, UIN Sunan Gunung Djati Bandung, artikel diterbitkan di jurnal Atthulab, Volume : IV, Nomor 1, 2019/1440 dengan judul "Desain Media Pembelajaran Pendidikan Agama Islam Berbasis Aplikasi Android Materi Pengurusan Jenazah Untuk Siswa Kelas XI Sekolah Menengah Kejuruan”. Tulisan ini mengulas tentan inovasi media pembelajaran pada pembelajaran PAI khususnya pada materi engurusan Jenazah Untuk Siswa Kelas XI SMK. Mengingat zaman sekarang adalah zaman digital, maka inovasi yang dilakukan adalah dengan menggunakan mobile learning berbasis android. Model pembelajaran yang digunakan pada tulisan ini adalah Model ADDIE. ${ }^{21}$

Kedua adalah tulisan Nahdliyyatul 'Azimah dan Rahman Hakim dari Universitas Islam Negeri Sunan Ampel Surabaya, yang berjudul "Eksplorasi Pembelajaran

20 Saifuddin Azwar, Metodologi Penelitian (Yogyakarta: Pustaka Pelajar, 2004), 5.

21 Rahmat Hidayat Hanafi, "Desain Media Pembelajaran Pendidikan Agama Islam Berbasis Aplikasi Android Materi Pengurusan Jenazah Untuk Siswa Kelas XI Sekolah Menengah Kejuruan”. 
M-learning Fiqh pada Masa Pandemi di UIN Sunan Ampel Surabaya”, yang diterbitkan di jurnal Atthulab: Islamic Religion Teaching \& Learning Journal Volume 5 Nomor 2 Tahun 2020. Penelitian ini mengulas tentang pembelajaran fiqh menggunakan mobile learning selama pandemi covid 19 di Fakultas Syariah dan Hukum UIN Sunan Ampel Surabaya, kegiatan pembelajaran terdiri dari pelaksanaan pembelajaran daring, media ajar, metode, dan evaluasinya. Hasil dari penelitan ini menemukan bahwa, smartphone sudah menjadi hal penting dalam dunia pendidikan sekarang ini. Karena tanpa disadari media sosial didalam smartphone dapat menjadi penunjang kegiatan perkuliahan mahasiswa baik dalam jam perkuliahan ataupun diluar jam kuliah. Melalui media sosial mahasiswa dapat merencanakan tugas, berbagi informasi tugas dengan rekan kelompoknnya. ${ }^{22}$

Ketiga adalah Tesis Bahar Nur Batubara dari Pascasarjana Universitas Islam Negeri Sunan Kalijaga yang berjudul "Pengembangan Media Pembelajaran Pendidikan Agama Islam berbasis Android di SMA UII Yogyakarta”. Penelitian tesis ini dilator belakangi oleh peserta didik yang sering memainkan smartphone ketika jam pelajaran PAI, terlebih peserta didik menjadi malas mencatat materi. Maka menurut guru PAI di SMA UII, perlu mengadakan inovasi media pembelajaran pada mata pelajaran PAI yaitu dengan menggunakan mobile learning. Setelah melakukan penelitian, ada 15 responden siswa terhadap media mobile learning pada aspek desain adalah skornya 3, 89 yang artinya “baik". Sedangkan dari aspek kuis skornya 5 artinya "sangat baik'. Dengan adanya respon positif dari peserta didik. Maka media pembelajaran menggunakan mobile learning dinilai layak untuk proses pembelajaran PAI. ${ }^{23}$

Keempat tulisan Andi Taufik dan Fattya Ariani dari STMIK Nusa Mandiri Riau, yang berjudul "Perancangan Mobile Learning untuk Meningkatkan dan Menarik Minat Belajar Ilmu Nahwu Berbasis Android”, diterbitkan di jurnal SATIN (Sains dan Teknologi Informasi) Vol. 6, No. 1, Juni 2020. Dalam tulisan ini mengulas sebuah rancangan pembuatan pernagkat lunak (aplikasi) pada smartphone untuk pembelajaran Ilmu nahwu. Agar kegiatan belajar ilmu nahwu tidak monoton dan lebih menarik, karena selain dapat belajar dimana saja dan kapan saja, para santri juga dapat bermain sambil belajar. ${ }^{24}$

22 Nahdliyyatul 'Azimah dan Rahman Hakim, "Eksplorasi Pembelajaran M-learning Fiqh pada Masa Pandemi di UIN Sunan Ampel Surabaya”, Jurnal Atthulab: Islamic Religion Teaching \& Learning Journal, Vol. 5 No. 2 (2020).

${ }^{23}$ Bahar Nur Batubara, "Pengembangan Media Pembelajaran Pendidikan Agama Islam berbasis Android di SMA UII Yogyakarta". 92-93.

24 Andi Taufik dan Fattya Ariani, "Perancangan Mobile Learning untuk Meningkatkan dan Menarik Minat Belajar Ilmu Nahwu Berbasis Android”, Jurnal SATIN (Sains dan Teknologi Informasi) Vol. 6, No. 1 (Juni 2020). 
Kelima tulisan dari Agus Purwanto yaitu seorang GPAI (Guru PAI) di SMAN 1 Gemolong Sragen. Dengan artikel yang berjudul "Pengembangan Aplikasi Mobile Learning Berbasis Android Sebagai Media Pembelajaran Pendidikan Agama Islam dan Budi Pekerti Pada Materi Iman Kepada Allah Untuk Peserta Didik Kelas X MIPA 3 SMA Negeri 1 Gemolong Tahun Pelajaran 2018/2019”, diterbitkan di Jurnal Pendidikan, Volume 28, Nomor 2, Juli 2019. Tujuan dari penelitian ini adalah untuk memberikan hal yang baru pada media pembelajaran PAI yaitu dengan menggunakan mobile learning berbasis android pada materi kelas X yaitu Iman Kepada Allah. Hasilnya, respon peserta didik baik dalam penerapan aplikasi mobile learning dalam materi Iman Kepada Allah. ${ }^{25}$

\section{HASIL PENELITIAN}

\section{Profil SMK Wahana Karya Surabaya}

SMK Wahana Karya merupakan salah satu SMK swasta di Surabaya yang bertempat di Jl. Mbah Wongso I, Dk. Karang Ploso Bangkingan, Kec. Lakarsantri Surabaya. Status kepemilikan SMK ini adalah dari yayasan pribadi, dimana Bapak Dibyo Dinarwo, ST sebagai Kepala Sekolah yang menaungi langsung sistem di SMK Wahana Karya. Surat ijin operasional didapatkan pada tahun 2017. Kemudian pada tahun 2019 mendapatkan akreditasi B berdasarkan hasil rapat pleno BAN S/M. ${ }^{26}$

Sekolah Menengah Kejuruan (SMK) setara dengan Sekolah Menengah Atas (SMA). Bedanya di Sekolah Menengah Kejuruan terdapat banyak program keahlian yang bisa dipilih oleh peserta didik sesuai dengan bakat dan minatnya. Setiap lembaga sekolah SMK menawarkan program keahlian yang berbeda-beda. SMK Wahana Karya menawarkan 2 program keahlian yaitu Teknik Permesinan (TPM) dan Multimedia (MM). secara keseluruhan peserta didik di SMK ini berjumlah 117 yang didominasi oleh peserta didik laki-laki yang berjumlah 107, sedang peserta didik perempuannya berjumlah $10{ }^{27}$

\section{Penerapan Mobile Learning Berbasis Android (Smarthphone) Dalam Pembelajaran Pendidikan Agama Islam di SMK Wahana Karya Surabaya}

Kecanggihan dalam teknologi dimanfaatkan dengan sebaik mungkin dalam pendidikan. Selain itu teknologi dianggap sebuah inovasi dalam dunia pendidikan sebagai media pembelajaran di zaman modern sekarang ini. Teknologi yang digunakan dalam

25 Agus Purwanto,"Pengembangan Aplikasi Mobile Learning Berbasis Android Sebagai Media Pembelajaran Pendidikan Agama Islam dan Budi Pekerti Pada Materi Iman Kepada Allah Untuk Peserta Didik Kelas X MIPA 3 SMA Negeri 1 Gemolong Tahun Pelajaran 2018/2019”, Jurnal Pendidikan, Vol. 28, No. 2 (Juli 2019).

26 Arsip Dokumen SMK Wahana Karya Surbaya. 25-11-2020.

27 Arsip Dokumen SMK Wahana Karya Surbaya. 25-11-2020. 
pembelajaran hendaknya memilih yang mudah diakses serta tersedia dengan mudah, merata di lignkup siswa dan guru. Maka penggunaan mobile learning dirasa cocok untuk pembelajaran PAI. Penggunaaan mobile learning berbasis android sebagai media pembelajaran pendidikan agama islam difokuskan pada memberikan platform pada kelaskelas pembelajaran online. Kelas online memberikan fasilitas interaksi antara peserta didik dan pendidik. Mobile learning juga memberikan ruang untuk materi ajar berupa video, ambar teks, ruang diskusi dan pemberian tugas. Pembelajaran PAI menggunakan mobile learning di SMK Wahana karya Surabaya menggunakan tujuh platform mobile learning berbasis android, dibawah ini merupakan penerapan ketujuh platform pada pembelajaran PAI:

\section{Google Classroom Melalui Android}

Pertama setiap pengguna diwajibkan download terlebih dahulu aplikasi classroom di android masing-masing. Download classroom melalui play store. Kedua, yaitu login ke dalam aplikasi classroom mengunakan email. Jika login menggunakan email akun G Suite for Education akan di beri pilihan "Saya seorang siswa" atau "Saya seorang pelajar". Jika login menggunakan akun pribadi tidak diberi pilihan tersebut. Ketiga, jika sudah memasuki akun google classroom, pengguna disarankan memberi foto profil. Keempat jika pengguna seorang pendidik, maka disarankan untuk membuat kelas yaitu dengan cara mengklik tanda “+”, klik buat kelas. Beri nama kelas sesuai dengan mata pelajaran yang diampu. Jika pengguna seorang siswa klik tanda “+” klik gabung kelas. Dengan memasukkan kode kelas dari guru.

Di dalam google classroom terdapat tempat forum dan tempat tugas. Peserta didik wajib mendownload aplikasi classroom sebagai media pembelajaran. Karena guru akan dapat menge-share tugas ke dalam classroom. Tugas yang di share di dalam classroom otomatis akan tersimpan dengan baik.

\section{WhatsApp Messenger Group}

WhatsApp Messenger atau yang biasa disebut dengan WA adalah teknologi yang berkembang saat ini. WA adalah aplikasi chat yan dapat menghubungkan antar satu dengan yang lainnya menggunakan jejaring internet dengan melalui perangkat android. WA adalah teknologi yang dinilai mampu untuk digunakan sebagai media pembelajaran yaitu dengan menggunakan whatsapp grup. WA grup dinilai memiliki potensi yang dapat 
digunakan untuk berdiskui terkait suatu pembelajaran. ${ }^{28}$ WA grup mendukung pembelajaran baik online ataupun offline. WA grup juga digunakan di SMK Wahana Karya sebagai pembelajaran PAI di kelas X, XI, XII baik itu di jurusan MM dan TPM.

Menurut Adhi Susilo grup WA mempunyai tiga manfaat yaitu pedagogis, sosial dan teknologi. Aplikasi ini sangat dapat mendukung adanya pembelajaran secara online. Dengan menggunakan grup wa para pengguna dapat menyampaikan pengumuman tertentu, berbagai ide, dan sumber belajar dan mendukung adanya diskusi secara online. ${ }^{29}$ Kepala Sekolah di SMK Wahana Karya menuturkan bahwa setiap kelas wajib membuat grup, maka saat ini ada enam kelas grup di SMK Wahana Karya. Hal ini guna untuk menyampaikan informasi-informasi terkait pembelajaran PAI, peserta didik dapat berkolaborasi, dengan adanya informasi-informasi yang dishare oleh pendidik akan berguna dalam pembelajaran. Keaktifan peserta didik dalam WA juga menjadi nilai plus, artinya peserta didik cepat tanggap dan kritis dalam menghadapi sesuatu. ${ }^{30}$

Manfaat yang dirasakan guru PAI SMK Wahana Karya dengan adanya aplikasi WA grup dalam pembelajaran PAI adalah: 1).WA grup menyediakan fasilitas yang dapat menunjang pembelajaran kolaboratif secara online baik di rumah atau di sekolah. 2). WA adalah aplikasi yang cukup ringan di android, gratis dan mudah digunakan, peserta didik tidak akan kesulitan. 3). WA grup dapat memberikan akses untuk berkomentar, membagi tulisan, gambar, video, suara, dan dokumen. 5) informasi yang diperoleh di WA grup dapat dengan mudah dishare dengan mudah ke platform lain. ${ }^{31}$

\section{Google Formulir Melalui Android}

Cara membuat soal melalui google formulir pada perangkat android adalah Pertama, pengguna mendownload terlebih dahulu Google formulir di Play Store dan menginstalnya. Kedua, jika sudah diinstal, buka aplikasi google form, klik tanda “+” di pojok kanan bawah. Setelah klik tombol + tersebut, akan muncul tampilan blank kosong. Ketiga, form title diisi dengan judul yang diinginkan, form description diisi dengan deskripsi yang dinginkan. Keempat, yaitu membuat form data klik tombol "Add item". Kemudian akan muncul berbagai macam form. Pendidik bisa memilih yang short answer, paragraph, atau pilihan ganda dan sebagainya. Kelima, Jika sudah selesai membuat soal klik

${ }^{28}$ Choki Barhomi, "Ectiveness of WhatsApp Mobile Learning Activities Guided by Activity eory on Students’ Knowledge Mangement”, Contemporary Educational Technology, Vol 6 (3), 2015,. 221-238

${ }^{29}$ Adhi Susilo, Exploring Facebook and Whatsapp As Supporting Social Network. Apllications For English Learning In Higher Education (Bandung: Widyatama, 2014), 10.

${ }^{30}$ Dibyo Dinarwo, Wawanacara, Kepala Sekolah SMK Wahana Karya Surabaya, 26-11-2020.

31 Sofia Zaini Kulbi, Wawancara, Guru PAI SMK Wahana Karya Surabaya, 27-11-2020 
tanda "ل" yang terletas diatas form. Maka akan muncul link yang dapat copy dan dibagikan kepada peserta didik melalui WA grup, Classroom dan sebagainya.

Salah satu peserta didik kelas X MM mengatakan bahwa dengan menggunakan google form, ia merasa mengerjakan soal menjadi lebih simple. Tetapi terkadang ada kendala yaitu sinyal atau koneksi yang buruk. Selain itu menggunakan google form dinilai sangat mudah. Karena peserta didik hanya tinggal mengklik link kemudian masuk ke dalam soal, dan mengerjakan soal tersebut, soal dapat dikerjakan kapan saja dan dimana saja.

Google form biasanya digunakan guru PAI SMK Wahana Karya untuk memberikan kuis-kuis, ulangan harian. Bentuk soal yang disediakan dapat berupa essai atau multiple choice (pilihan ganda). Manfaat bagi guru menggunakan google form adalah data-data dari jawaban peserta didik akan tersimpan secara otomatis, pengkoreksian juga praktis serta dapat dilakukan kapan saja dan dimana saja selama ada perangkat android. Beda halnya dengan ujian tertulis dikertas yang jawabannya terkadang dapat terselip, sobek, dan basah. Contoh soal menggunakan google formulir pada materi: https://bit.ly/tugas8PAIkelasXI

\section{You Tube}

You tube juga dapat digunakan sebagai media pembelajaran PAI. Setiap android pasti mempunyai aplikasi you tube, aplikasi you tube adalah platform yang menyediakan konten berupa video. Guru PAI di SMK Wahana Karya beberapa kali menggunakan you tube dalam pembelajaran PAI. Guru dapat mengambil materi berupa video dari orang lain atau membuat video di channel sendiri. Contohnya dalam materi 'Adab Berpakaian Menurut Syariat Islam". Contohnya dapat dilihat dengan mengklik link ini: https://bit.ly/materikelasXadabberpakaian

\section{Ms. Sway Melalui Android}

Microsoft Sway adalah aplikasi keluaran terbaru dari Microsoft Office yang memberikan kemudahan untuk membuat laporan, presentasi yang menarik dan interaktif. Ms Sway dapat digunakan oleh siapa saja yang mempunyai akun Microsoft. Ms. Sway tersedia di Sway.com dan windows 10, maka ms.sway dapat diakses di beragam browser seperti google chroom, mozila dan sebagainya. Guru PAI di SMK Wahana Karya menggunakan sway dalam pembelajaran PAI. Dalam ms. Sway juga dapat diisi oleh berbagai macam platform lain. Contohnya dapat diisi dengan Ms. Form atau video dari 
youtube. Ms. Sway juga dapat digunakan di android selama pembuat ms.sway sudah mempunyai akun Microsoft. Sedangkan pembaca tidak wajib mempunyai ms.sway.

Cara membuat Ms. Sway diandroid yaitu 1) dengan menggunakan browser atau google chroom. Saat di browser pengguna perlu menulis kata kunci "Ms.Sway". 2) Jika sudah masuk ke platform ms.sway pengguna wajib login terlebih dahulu dengan memasukkan email dan kata sandi yang sudah dibuat melalui Microsoft. 3) jiks sudah masuk pada halaman sway maka klik "buat baru", silahkan ketik judul dan konten ada di kolom sway. Pengguna bisa mengubah desain yang disukai. 4) Jika dirasa sudah, klik simpan dan bagikan link sway ke WA atau platform lain. Contoh materi Ms.Sway pada Bab 2 PAI kelas X Materi "Mengenal Allah Melalui Asmaul Husna". Klik link https://bit.ly/MateridanTugas3PAIKlsX

\section{Ms. Power Point melalui Android}

Ms. Power Point terkadang juga digunakan sebagai media pembelajaran PAI di SMK Wahana Karya. Pendidik dapat membuat power point melalui android dengan mendownload terlebih dahulu aplikasi power point di playstore. Setelah di download, pendidik merangkum materi semenarik mungkin di slide-slide yang tersedia di power point, sebisa mungkin menggunakan bahasa yang sederhana dan mudah dimengerti oleh peserta didik. Jika sudah membuat materi, pendidik mengshare file power poin tersebut melalui WA grup atau di classroom. Dengan menggunakan power point peserta didik akan memahami garis besar materi yang disampaikan oleh pendidik. Peserta didik dapat mempelajari materi dengan power point kapan saja dan dimana saja baik secara online maupun offline. Dibawah ini adalah contoh power point yang dipelajari oleh peserta didik pada pembelajaran PAI di SMK Wahana Karya. Contoh power point yang dibuat oleh guru SMK Wahana Karya Surabaya pada materi "Mujahadah an-Nafs, Husnudzan dan Ukhuwah",Klik link https://bit.ly/MaterikelasXPAImujahadahannafs

\section{Aplikasi Sejarah Agama Islam melalui Android}

Terakhir adalah penggunaan aplikasi "Sejarah Agama Islam” sebagai media pembelajaran PAI. Peserta didik diarahan untuk mendownload aplikasi "Sejarah Agama Islam" di playstore. Setelah itu peserta didik membuka aplikasi, saat membuka aplikasi peserta didik disuguhkan oleh berbagai menu diantaranya, Sejarah Agama Islam; AlQur'an; Juz Amma; Belajar Ilmu Tajwid; Surat yasin; Audio Surat Yasin; Doa dan Dzikir. Namun guru PAI di SMK Wahana Karya cenderung menggunakan aplikasi ini hanya pada empat menu yaitu, pertama Sejarah Agama Islam, selain diberi penjelasan tentang sejarah 
Islam oleh guru saat pembelajaran PAI. Peserta didik disarankan oleh guru untuk membaca sejarah Islam saat belajar sendiri menggunakan aplikasi ini, karena aplikasi ini dapat digunakan secara offline, peserta didik tidak perlu menggunakan kuota. Kedua, menu al-Qur'an yang digunakan saat praktek mengaji dikelas. Ketiga, menu juz amma, yang digunakan dikelas saat praktek mengaji. Keempat, belajar ilmu tajwid, belajar ilmu tajwid digunakan peserta didik saat dikelas, Guru PAI menerangkan sambil peserta didik melihat materi yang ada di aplikasi.

\section{Potensi Penggunaan Mobile Learning Berbasis Android (Smarthphone) Dalam Pembelajaran Pendidikan Agama Islam di SMK Wahana Karya Surabaya}

Berdasarkan ketujuh penerapan platform mobile learning dalam pembelajaran PAI. Serta setelah melakukan pengumpulan data melalui observasi dan wawancara kepada kepala sekolah, guru PAI dan beberapa siswa siswi di SMK Wahana Karya Surabaya. Maka penulis dapat menganalisis sejauh mana potensi penggunaan mobile learning berbasis android dalam pembelajaran PAI di SMK Wahana Karya Surabaya. Kepala sekolah SMK Wahana Karya Surabaya yaitu Bpk. Dibyo Dinarwo, ST, sangat mengapresiasi jika pembelajaran diberikan inovasi atau pembaharuan khususnya dalam media pembelajarannya. Karena menurut bapak. Dibyo media pembelajaran harus memiliki fungsi yang dapat memperluas informasi, dan dapat mendorong motivasi belajar peserta didik. Media yang digunakan guru dalam pembelajaran memerlukan inovasi agar siswa dapat lebih aktif saat pembelajaran. ${ }^{32}$

Hal ini selaras dengan yang dikatakan Rohani bahwa media pembelajaran harus mempunyai fungsi yaitu 1) menyampaikan informasi, 2) memperkaya informasi dalam pembelajaran, 3) dapat memberikan motivasi belajar untuk peserta didik, 4) dapat menambah inovasi dan variasi dalam memberikan materi ke peserta didik, 5) mudah difahami oleh peserta didik. ${ }^{33}$

Bapak Dibyo Dinarwo berpendap at bahwa mobile learning berbasis android dapat menjadi solusi dalam pembelajaran di zaman digital. Karena penggunaan mobile learning dirasa cukup mudah, akses yang gratis dan peserta didik dapat mengakses berbagai sumber belajar dan gaya belajar menjadi lebih menarik contohnya menggunakan ms.sway yang memiliki template yang cantik. Untuk melaksakan dan memakai mobile learning berbasis android dalam pembelajaran, segala persiapan harus dipenuhi terlebih

\footnotetext{
32 Dibyo Dinarwo, Wawanacara, Kepala Sekolah SMK Wahana Karya Surabaya, 26-11-2020.

${ }_{33}$ Rohani, Media intruksional Edukatif (Jakarta: Rineka Cipta, 1997), 9.
} 
dahulu, mulai dari tenaga pendidik, sarana prasarana dan jaringan yang mumpuni serta siswa yang paham akan teknologi IT. ${ }^{34}$

Oleh karenanya, dalam upaya mendukung pembelajaran dengan menggunakan mobile learning berbasis android pihak sekolah menyediakan beberapa PC bagi peserta didik yang belum mempunyai smartphone dan menyediakan wifi di sekolahan untuk peserta didik dan guru. Selain platform yang beragam dalam mobile learning, menurut Bapak Dibyo dapat memberikan motivasi semangat belajar bagi peserta didik. Karena dengan mengakses di berbagai website dan platform, peserta didik akan merasa pembelajaran PAI menjadi menyenangkan dan mereka akan tertarik dengan materi yang disediakan. ${ }^{35}$

Bapak Ibnu Purnomo Guru PAI kelas XII menuturkan bawah Mata pelajaran PAI adalah mata pelajaran wajib dalam semua jenjang pendidikan dan dalam setiap instansi sekolah untuk peserta didik yang beragama Islam. Materi dari PAI berisi ajaranajaran yang terdapat di dalam agama Islam. Maka, secara umum pembelajaran PAI selalu menggunakan metode ceramah, dikarenakan materi PAI yang cenderung bersifat teoritis. Hal ini merupakan suatu problem pada pembelajaran PAI. Karena siswa akan pasif dan bosan jika hanya menggunakan metode ceramah. ${ }^{36}$

Ibu Sofia Zain sebagai Guru PAI kelas X dan XI menyetujui apa yang disampaikan Bapak.Ibnu dengan menambahi, bahwa pembelajaran PAI sebelum menggunakan media mobile learning berbasis android, peserta didik terlihat tidak bersemangat saat pembelajaran PAI, terutama dalam hal mencatat dan membaca materi. Terlebih saat mendengar ceramah materi tentang sejarah agama Islam, peserta didik terlihat tidak fokus dan beberapa peserta didik tanpa sadar akhirnya tertidur dikelas. ${ }^{37}$

Menurut salah satu siswa kelas XI TPM menyampaikan pendapatnya bahwa belajar tentang sejarah agama Islam lebih menyenangkan melalui youtube atau menonton film peperangan dari pada mendengarkan ceramah. ${ }^{38}$ Berdasarkan permasalahan tersebut, maka guru PAI di SMK Wahana Karya mencari alternative dengan memberikan pembelajaran sejarah agama Islam melalui film, agar peserta didik lebih bersemangat dalam menyimak materi. Setelah melihat film, tentu peserta didik masih dijelaskan inti materi dari film tersebut oleh guru.

\footnotetext{
${ }^{34}$ Dibyo Dinarwo, Wawanacara, Kepala Sekolah SMK Wahana Karya Surabaya, 26-11-2020.

35 Ibid.,

${ }^{36}$ Ibnu Purnomo, Wawancara, Guru PAI SMK Wahana Karya Surabaya, 27-11-2020.

${ }^{37}$ Sofia Zain Kulbi, Wawancara, Guru PAI SMK Wahana Karya Surabaya, 27-11-2020

${ }^{38}$ Salah satu siswa kelas XI TPM SMK Wahana Karya Surabaya, Wawancara, 26-11-2020.
} 
Selain termausk inovasi dalam pembelajaran PAI, mobile learning berbasis android memudahkan pendidik dalam membuat materi, membuat penugasan untuk peserta didik, serta membuat evaluasi atau penilaian. ${ }^{39}$ Pembuatan materi untuk peserta didik dibuat menjadi menarik dengan menggunakan platform yang tersedia diperangkat android seperti menggunakan youtube, ms.sway, power point dan google form untuk penugasan. Serta membuatnya dapat kapan saja dna dimana saja.

Membuat soal tugas akan mudah dengan menggunakan google form, terlebih dengan menggunakan google forms penyimpanannya menggunakan google drive. Jadi, pendidik tidak perlu khawatir data soal yang dibuat akan hilang. Beda halnya membuat soal dengan cara manual yaitu menggunakan kertas, yang dikhawatirkan berkasnya akan tidak karuan. Begitu pula perihal penilaian tugas, dengan google form pendidik dapat melakukan pengoreksian secara langsung dengan menggunakan pengaturan di google form. Setiap soal diberi point, maka jika peserta didik selesai mengerjakan tugas, dengan otomatis nilai akan muncul dengans sendirinya.

Kemajuan teknologi saat ini sangat membantu pula dalam aspek pendidikan. Peserta didik dan pendidik selalu dapat terhubung dan berinteraksi menggunakan kelas online. Guru PAI SMK Wahana Karya memanfaatkan mobile learning berbasis android untuk pembelajaran secara online yaitu dengan mengunakan platform google classroom dan WA. Meski tidak sedang berada dikelas, pembelajaran dapat tetap berlansung melalui kelas online, peserta didik dapat ebrdiskusi perihal materi PAI di kelas online tersebut. Hal ini sangat cocok digunakan untuk pembelajaran daring seperti saat pandemic covid 19, yang pembelajaran dilakukan di rumah.

Kedua Guru PAI kelas di SMK Wahana Karya sama-sama menyetujui bahwa pendidik harus memiliki metode baru dalam mengembangkan pembelajaran, agar peserta didik aktif dan merasa tertarik dengan mata pelajaran PAI. Pendidik tetap memakai metode lama tetapi juga mengkolaborasikan dengan metode zaman digital ini yang difasilitasi oleh mobile learning berbasis android. Karena android adalah smartphone yang menyediakan kemudahan dalam proses pembelajaran. Terlebih peserta didik di zaman sekarang rata-rata sudah menggunakan smartphone. Maka pembelajaran PAI dengan

39 Andi Taufik dan Fattya Ariani, "Perancangan Mobile Learning untuk Meningkatkan dan Menarik Minat Belajar Ilmu Nahwu Berbasis Android”, 29. 
menggunakan media mobile learning berbasis android dirasa sangat sesuai di zaman sekarang. ${ }^{40}$

Dari berbagai kelebihan platform mobile learning berbasis android, Bapak. Dibyo sebagai kepala sekolah menghimbau untuk memperhatikan saat pembelajaran dengan mobile learning. Contohnya, guru PAI harus lebih teliti lagi dalam mengkondisikan siswa saat proses belajar mengajar. Agar pembelajaran berjalan lancar dan tidak memakan waktu yang sia-sia. Berdasarkan beragam pendapat dari wawancara tersebut. ${ }^{41}$ Penulis dapat membuat kesimpulan bahwa pembelajaran PAI dengan menggunakan mobile learning berbasis android di SMK Wahana Karya Surabaya adalah hal yang tepat dan dinilai bagus. Selain mobile learning berbasis android merupakan sebuah invoasi dalam pembelajaran PAI di zaman digital ini.

Manfaat belajar menggunakan mobile learning berbasis android juga dirasakan oleh peserta didik. Beberapa siswa perwakilan dari kelas X, XI, dan XII mengungkapkan hal yang sama tentang pembelajaran PAI menggunakan platform mobile learning. Para siswa mengatakan bahwa pembelajaran PAI menjadi sangat menyenangkan. Karena, pembelajaran PAI jadi lebih inovatif dan tidak membuat jenuh, serta peserta didik dapat lebih aktif berpendapat dan bertanya. Peserta didik mengaku cepat memahmi materi dengan menggunakan sumber-sumber yang difasilitasi oleh platform mobile learning.

\section{Kendala dan Solusi Penggunaan Mobile learning Berbasis Android (Smarthphone) dalam pembelajaran Pendidikan Agama Islam di SMK Wahana Karya Surabaya}

Meskipun Mobile Learning berbasis android menawarkan berbagai kemudahan dalam kegiatan pembelajaran. Namun dalam pemanfaatan mobile learning pada pembelajaran PAI di SMK Wahana Karya Surabaya, kerapkali ada kendala yang dirasakan peserta didik dan pendidik, seperti: 1) Saat pembelajaran menggunakan mobile learning, pengguna membutuhkan hardware atau perangkat keras, software atau perangkat lunak. Sedangkan tidak semua peserta didik di SMK Wahana Karya Surabaya mempunyai perangkat keras seperti Laptop, PC, atau handphone. 2) Kesalahan pola pikir dari beberapa orang tua yang menanggap penggunaan android dalam pembelajaran PAI adalah suatu hal yang negative. Beberapa orang tua tidak setuju dengan penggunaan mobile learning dalam pembelajaran, dikhawatirkan peserta didik akan menyalahgunakan android untuk hal yang negatif.

40 Ibnu Purnomo, Wawancara, Guru PAI SMK Wahana Karya Surabaya, 27-11-2020.

${ }^{41}$ Dibyo Dinarwo, Wawanacara, Kepala Sekolah SMK Wahana Karya Surabaya, 26-11-2020. 
3) Kesulitan dalam mengelola suasana saat pembelajaran. Setiap kelas di SMK Wahana Karya terdiri sekitar 20. Pembelajaran menggunakan mobile learning membutuhkan pengawasan yang ketat, terlebih di SMK Wahana Karya didominasi oleh peserta didik laki-laki yang hobi bermain game online. Dalam hal ini dikhawatirkan peserta didik akan menyalahgunakan android untuk game bukan untuk pembelajaran. 4) Jaringan internet yang terkadang bermasalah. 5) Waktu yang terbatas, karena adanya beberapa peserta didik dan pendidik yang masih tidak menguasai teknologi informasi, maka waktu akan terpotong untuk belajar platform mobile learning dibanding memperlajari pembelajaran PAI. ${ }^{42}$

Beberapa kekurangan yang disebutkan oleh guru PAI yang mempengaruhi pembelajaran PAI dengan menggunakan OER menjadi terhambat. Maka guru PAI perlu menyiapkan berbagai solusi untuk menangani hal tersebut. Dalam wawancara dengan penulis, guru PAI di MAN 1 Pasuruan sudah mempersiapkan solusi dalam mengatasi problem tersebut diantaranya: 1). Pihak sekolah memberikan info kepada orang tua peserta didik, agar peserta didik dibekali handphone saat pembelajaran PAI, dikarenakan ada materi yang membutuhkan handphone dalam pembelajaran. Jika memang ada keluarga peserta didik yang tidak mempunyai handphone. Maka solusinya pihak sekolah menyediakan PC atau computer agar dapat digunakan peserta didik dalam pembelajaran menggunakan android. Dalam hal ini pihak sekolah SMK Wahana Karya Surabaya sudah menyediakan sekitar 20 PC yang dapat dimanfaatkan peserta didik dalam pembelajaran PAI.

2). Baik Kepala sekolah atau pendidik memberikan pemahaman kepada orang tua tentang manfaat mobile learning berbasis android dalam pembelajaran. kepala sekolah mengadakan pertemuan dengan wali murid, dan memberi tahu bahwa dengan menggunakan android siswa siswi akan dapat pengetahuan secara lebih luas. 3). Agar pembelajaran dapat berjalan secara efektif dalam penggunaan media mobile learning di SMK Wahana Karya maka pengelolaan kelas dalam pembelajaran PAI menggunakan mobile learning, harus ada dua guru di dalam kelas. Hal ini guna memantau siswa laki-laki yang dikhawatirkan akan menyalahgunakan android untuk bermain game saat pembelajaran berlangsung.

42 Agus Purwanto, "Pengembangan Aplikasi Mobile Learning Berbasis Android Sebagai Media Pembelajaran Pendidikan Agama Islam dan Budi Pekerti Pada Materi Iman Kepada Allah”, 199-200. 
4). Dalam hal ini solusinya ada dau cara yaitu pertama mengantisipasi jika wifi sekolah SMK Wahana Karya terkendala, maka pendidik harus mengkases materi secara offline contohnya seperti: mendownload video youtube tentang sejarah peperangan pada masa nabi, bab tata cara sholat jenzah, agar saat wifi terkendala peserta didik dapat melihat video yang sudah di download. Kedua memberikan paket data kepada peserta didik, agar dapat digunakan saat dirumah. 5). Pihak sekolah memberikan pelatihan mobile learning berbasis android, pelatihan diluar jam belajar tentang penggunaan classroom, Ms. Sway, Ms Power Point, Aplikasi yang ada di android. Hal ini dilakukan Agar saat pembelajaran PAI waktu tidak terbuang sia-sia.

Berdasarkan hal tersebut, dalam implementasi pemanfaatan OER pada pembelajaran PAI, seorang pendidik bertanggung jawab penuh dalam menyediakan media belajar yang dibutuhkan oleh peserta didik. Pendidik juga bertanggung jawab mencari solusi pada permasalahan yang ada saat pembelajaran. Agar pembelajaran dapat berjalan efektif dan efisien serta sesuai dengan tujuan pembelajaran.

\section{KESIMPULAN}

Berdasarkan penjelasan sebelumnya, maka dapat disimpulkan bahwa potensi pemanfaatan mobile learning berbasis android dalam pembelajaran PAI di SMK Wahana Karya Surabaya dinilai efektif dan menarik. Pembelajaran PAI menggunakan media mobile learning berbasis android di dukung oleh kepala sekolah, segenap guru dan siswa. Wujud dukungan pihak sekolah pada mobile learning sebagai media pembelajaran adalah diwujudkan dengan pemasangan wifi dan pengadaan PC bagi peserta didik yang belum mempunyai smartphoneatau android. Platform yang digunakan guru PAI di SMK Wahana Karya pada pembelajaran PAI adalah Google classroom, WA grup, Ms. Power Point, Ms. Sway, youtube, google formulir, dan Aplikasi Sejarah Agama Islam. Pemanfaatan mobile learning berbasis android pada pembelajaran PAI dinilai menjadi salah satu stratgei yang bagus untuk guru PAI dan siswa di SMK Wahana Karya. Peserta didik menjadi antusias, dan bersemangat dibanding dengan menggunakan metode ceramah. Sedangkan pendidik dapat menjadi lebih fleksibel dalam membuat materi, penugasan untuk siswa dan penilaiannya. 


\section{REFERENSI}

A. Arsyad, Media Pembelajaran, Jakarta: Raja Grafindo Persada, 2014

Adhi Susilo, Exploring Facebook and Whatsapp As Supporting Social Network. Apllications For English Learning In Higher Education, Bandung: Widyatama, 2014.

Agus Purwanto,"Pengembangan Aplikasi Mobile Learning Berbasis Android Sebagai Media Pembelajaran Pendidikan Agama Islam dan Budi Pekerti Pada Materi Iman Kepada Allah Untuk Peserta Didik Kelas X MIPA 3 SMA Negeri 1 Gemolong Tahun Pelajaran 2018/2019”, Jurnal Pendidikan, Vol. 28, No. 2 (Juli 2019).

Andi Taufik dan Fattya Ariani, "Perancangan Mobile Learning untuk Meningkatkan dan Menarik Minat Belajar Ilmu Nahwu Berbasis Android”, Jurnal SATIN (Sains dan Teknologi Informasi) Vol. 6, No. 1 (Juni 2020).

Anwar Sutoyo, Manusia dalam Perspektif al-Qur'an, Yogyakarta: Pustaka Pelajar, 2015.

Arsip Dokumen SMK Wahana Karya Surbaya. 25-11-2020.

Azyumardi Azra, Pendidikan Islam Tradisi dan Modernisasi Menuju Millennium Baru, Jakarta: Logos Wacana Ilmu, 1999.

Bahar Nur Batubara, "Pengembangan Media Pembelajaran Pendidikan Agama Islam berbasis Android di SMA UII Yogyakarta" (Tesis diterbitkan di Pascasarjana Fakultas Tarbiyah dan keguruan Universitas Islam Negeri Sunan Kalijaga, 2017).

Choki Barhomi “ e Eff ectiveness of WhatsApp Mobile Learning Activities Guided by Activity teory on Students' Knowledge Mangement" Contemporary Educational Technology, Vol 6 (3).

Dibyo Dinarwo, Wawanacara, Kepala Sekolah SMK Wahana Karya Surabaya, 26-11-2020.

Ibnu Purnomo, Wawancara, Guru PAI SMK Wahana Karya Surabaya, 27-11-2020.

Lexy J. Moleong, Penelitian Kualitatif, Bandung: Remaja Rosda Karya, 2001.

Muhammad Athiyah al-Abrasyi, Dasar-Dasar Pokok Pendidikan Agama Islam, Jakarta: Bulan Bintang, 1970.

Musahrain, Nunuk Suryani dan Suharno, "Pengaplikasian Mobile LearningSebagai Media dalam Pembelajaran", Prosiding Seminar Pendidikan Nasional Pemanfaatan Smartphone untuk Literasi Produktif Menjadi Guru Hebat dengan Smartphone, Pascasarjana Teknologi Pendidikan FKIP Universitas Sebelas Maret (2017)

Nahdliyyatul 'Azimah dan Rahman Hakim, "Eksplorasi Pembelajaran M-learning Fiqh pada Masa Pandemi di UIN Sunan Ampel Surabaya", Jurnal Atthulab: Islamic Religion Teaching \& Learning Journal, Vol. 5 No. 2 (2020). 
Nurdyansyah dan Fahyuni E.F, Inovasi Model Pembelajaran: Sesuai Kurikulum 2013, Sidoarjo: Nizamial Learning Centre, 2016.

Rahmat Hidayat Hanafi, "Desain Media Pembelajaran Pendidikan Agama Islam Berbasis Aplikasi Android Materi Pengurusan Jenazah Untuk Siswa Kelas XI Sekolah Menengah Kejuruan", Jurnal Atthulab, Vol. IV, No 1 (2019).

Rohani, Media intruksional Edukatif, Jakarta: Rineka Cipta, 1997.

Rusadi, B. E., Widiyanto, R., dan Lubis, R. R, Analisis Learning And Inovation Skills Mahasiswa PAI Melalui Pendekatan Saintifik Dalam Implementasi Keterampilan Abad 21, Conciencia, Vol. XIX, No. 2 (2019).

Saifuddin Azwar, Metodologi Penelitian, Yogyakarta: Pustaka Pelajar, 2004.

Siswa-siswi kelas X, XI, XII, Wawancara, 26-11-2020.

Siti Muyaroah dan Mega Fajartia, Pengembangan Media Pembelajaran Berbasis Android dengan menggunakan Aplikasi Adobe Flash CS 6 pada Mata Pelajaran Biologi, IJCET Vol 6 No 2 (2017).

Sofia Zain Kulbi, Wawancara, Guru PAI SMK Wahana Karya Surabaya, 27-11-2020

Syaafaruddin dan Anzizhan, Psikologi Organisasi dan Manajemen, Prenada Media Group, 2018. Syafaruddin, Inovasi Pendidikan: Suatu Analisis Terhadap Kebijakan Baru Pendidikan, Perdana Publishing: 2018.

Zakiyah Drajat, Ilmu Pendidikan Islam, Jakarta: Bumi Aksara, 2012.

Ziaurrahman, Herman Dwi Surjono, "Pengembangan E-Learning Adaptif Pada Mata Pelajaran Pendidikan Agama Islam Untuk Kelas X SMA”, Jurnal Inovasi Teknologi Pendidikan, Vol. 4, No. 2 (Oktober 2017). 